\author{
JURNAL EINSTEIN \\ Jurnal Hasil Penelitian Bindang Fisika \\ Available online http://jurnal.unimed.ac.id/2012/index.php/einsten \\ e-issn: $2407-747 x$, p-issn $2338-1981$
}

\title{
PENENTUAN MINERAL KALSIT DAN DOLOMIT PADA CITRA HASIL THIN SLICE BATUAN KARBONAT MENGGUNAKAN JARINGAN SYARAF TIRUAN BERBASIS MATLAB
}

\author{
Siti Hajar, Ridwan A. Sani \\ Jurusan Fisika, Fakultas Matematika dan Ilmu Pengetahuan Alam, Universitas Negeri Medan, \\ Indonesia \\ hajarpohan@gmail.com
}

Diterima Februari 2018; Disetujui Februari 2018; Dipublikasikan Februari 2018

\begin{abstract}
ABSTRAK
Telah dilakukan penelitian yang berjudul penentuan mineral kalsit dan dolomit pada citra sayatan tipis batuan karbonat menggunakan metode jaringan syaraf tiruan berbasis Matlab dengan tujuan untuk pengembangan metode petografi thin slice batuan. Pada penelitian ini dilakukan identifikasi mineral kalsit dan dolomit menggunakan metode pengolahan citra hasil thin slice batuan karbonat. Metode pengolahan citra yang digunakan pada penelitian ini adalah metode jaringan syaraf tiruan Extreme Learning Machine (ELM) dan ekstraksi ciri menggunakan metode Gray Level Co-occurrence Matrix (GLCM). Hasil dari penelitian meunjukkan keberhasilan program dapat mengidentifikasi mineral kalsit dan dolomit dengan besar persentase keberhasilan mencapai $90 \%$.
\end{abstract}

Kata Kunci : Kalsit, Dolomit, Matlab, Jaringan Syaraf Tiruan

\section{PENDAHULUAN}

Indonesia memiliki banyak bahan galian yang digunakan sebagai bahan baku industri. Hal tersebut ditandai dengan meningkatnya kegiatan eksplorasi yang dilakukan oleh pemerintah dan pihak swasta. Kegiatan eksplorasi tersebut dilakukan untuk memenuhi kebutuhan bahan baku industri. Salah satu bahan baku industri yang banyak di eksplorasi adalah batu gamping [1].

Mineral batu gamping yang paling dibutuhkan untuk pembuatan semen adalah mineral kalsit. Secara umum, penelitian mengenai batuan karbonat dapat dibagi menjadi beberapa aspek salah satunya adalah petrografi thin slices. Melalui petrografi dapat diketahui jenis, bentuk, tekstur dan komposisi suatu batuan. Secara kualitatif petografi dapat dilakukan melalui pewarnaan (staining) karena merupakan teknik yang paling mudah dan sederhana [2].

Analisa dengan menggunakan sayatan tipis bisa dipadukan dengan analisa tetes zat Alizarin Red S dimana zat ini akan memberikan perbedaan warna pada mineral yang terdapat pada batuan karbonat. Perbedaan warna tersebut dapat dianalisis lebih lanjut dengan mengambil gambar atau citra dari sayatan tipis batuan. Perbedaan warna dari citra digital dapat dikenali dengan menggunakan metode jaringan syaraf tiruan. Berdasarkan uraian tersebut maka mineral batuan karbonat khususnya kalsit dan dolomit dapat dikenali dengan menggunakan metode jaringan syaraf tiruan [3].

Jaringan syaraf tiruan yang digunakan pada penelitian ini adalah jaringan syaraf tiruan 
Extreme learning Machine. Jaringan syaraf tiruan ini dipilih karena merupakan salah satu jaringan syaraf tiruan feedforward dengan satu hidden layer atau lebih dikenal dengan istilah single hidden layer feedforward neural network (SLFN) dengan waktu analisis yang lebih cepat [4].

\section{METODE PENLITIAN}

Penelitian pembuatan program dilakukan menggunakan aplikasi Matlab. Metode penelitian yang telah dilakukan dalam merancang program menentukan mineral kalsit dan dolomit pada citra hasil thin slice batuan karbonat adalah sebagai berikut :

1. Citra masukan yang digunakan adalah citra RGB dari thin slice batuan karbonat yang telah ditetesi zat alizarin red-s sehingga mineral kalsit dan dolomit tampak dalam warna yang berbeda.

2. Kemudian citra tersebut dikelompokkan menjadi citra yang dikenal sebagai citra mineral kalsit dan citra yang dikenal sebagai mineral dolomit dengan metode cropping citra.

3. Menentukan data citra pelatihan dan data citra pengujian.

4. Data citra pelatihan dan data citra pengujian akan di resizing (pengubahan ukuran citra) dan juga grayscalling (mengubah citra menjadi citra keabuan).

5. Citra yang telah diubah menjadi citra keabuan akan di kenali ciri-cirinya oleh metode Gray Level Co-Occurance Matriks (GLCM).

6. Setelah citra dikenali ciri-cirinya maka metode Extreme Learning Machine (ELM) akan melakukan klasifikasi terhadap citra yang diuji sehingga citra tersebut dapat dikenali sebagai mineral kalsit atau mineral dolomit.

Diagram alir program dapat dilihat pada gambar 4 dibawah ini :

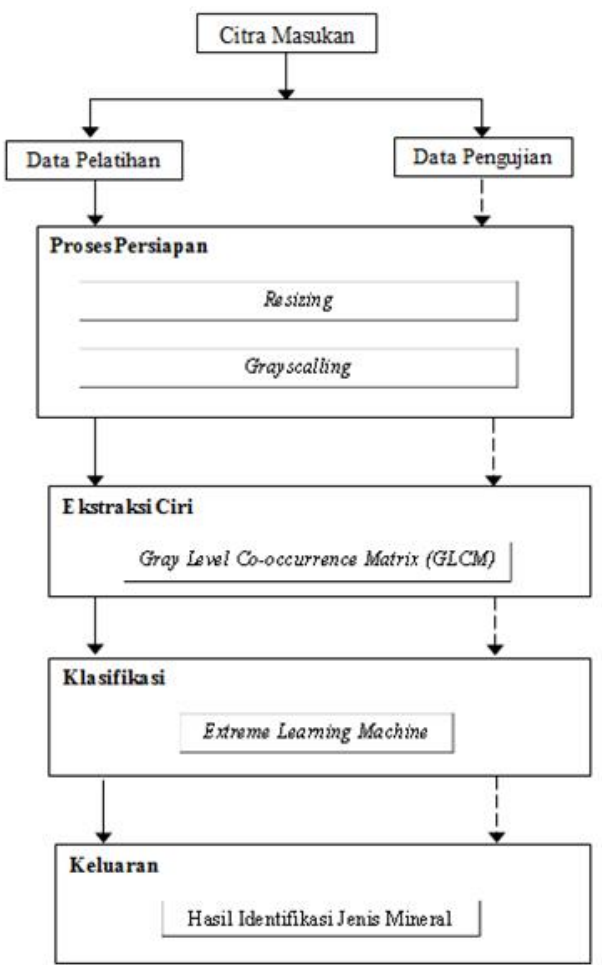

Gambar 1. Diagram Alir Pembuatan Program

\section{HASIL DAN PEMBAHASAN}

Telah dirancang sebuah program komputer untuk mengenali citra hasil thin slice batuan karbonat sebagai citra mineral kalsit atau citra mineral dolomit. tampilan program komputer yang telah dibuat adalah seperti gambar 5 berikut :

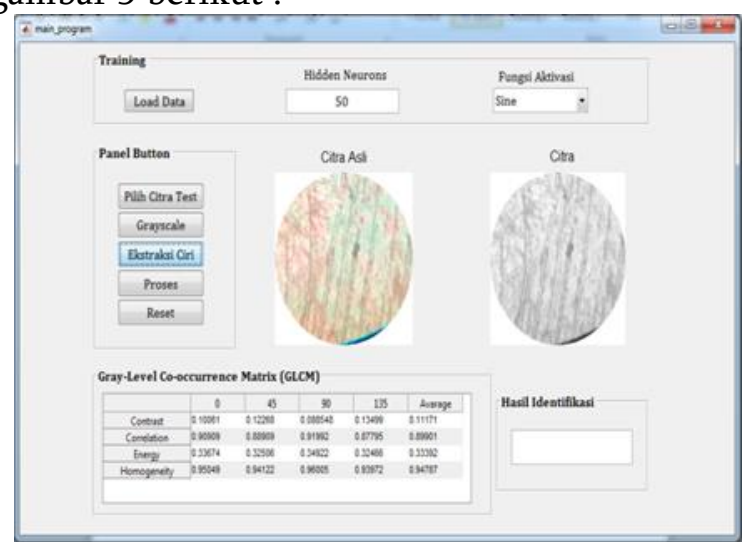

Gambar 2. Tampilan program untuk mengenali citra mineral kalsit dan dolomit

Sistem kerja dari program ini adalah ketika kita melakukan load data pada program, program akan membaca data inti dari sistem. Kemudian program akan meminta memasukkan jumlah hidden neuron, fungsi aktivasi, dan citra yang akan diuji. Setelah data masukan terpenuhi makan program akan melakukan analisis terhadapa citra masukan sehingga citra tersebut 
dapat dikenali sebagai citra mineral kalsit atau citra mineral dolomit. Contoh hasil identifikasi citra uji dapat dilihat pada gambar 6 berikut :

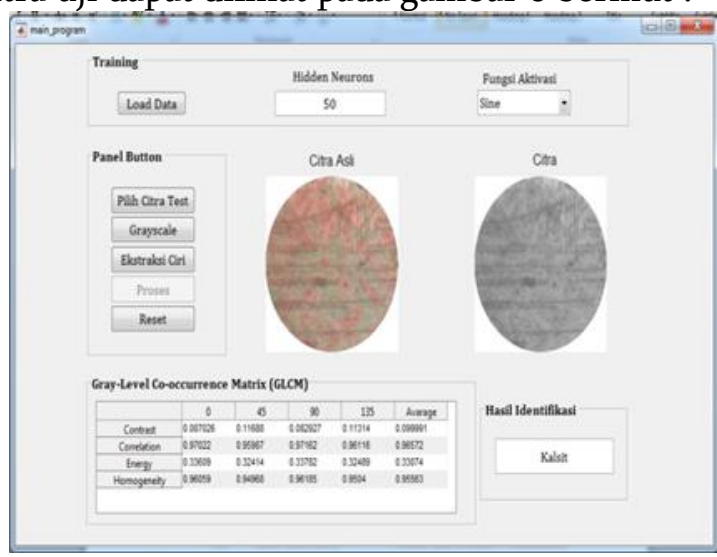

Gambar 3. Hasil identifikasi citra pengujian program

Setelah melakukan beberapa pengujian pada program maka didapatlah data sebagai berikut :

Tabel 1. Hasil Seluruh pengujian yang telah dilakukan

\begin{tabular}{|c|c|c|c|c|c|c|}
\hline \multirow{4}{*}{ Jumlah } & \multicolumn{9}{|c|}{ Fungsi aktivasi } \\
\cline { 2 - 7 } Neuron & \multicolumn{2}{|c|}{ Sigmoid } & \multicolumn{2}{c|}{ Sine } & \multicolumn{2}{c|}{ Radial Basis } \\
\cline { 2 - 7 } & $\begin{array}{c}\text { Jumlah } \\
\text { Citra } \\
\text { berhasil } \\
\text { dikenali }\end{array}$ & $\begin{array}{c}\text { Jumlah } \\
\text { citra } \\
\text { tidak } \\
\text { berhasil } \\
\text { dikenali }\end{array}$ & $\begin{array}{c}\text { Jumlah } \\
\text { Citra } \\
\text { berhasil } \\
\text { dikenali }\end{array}$ & $\begin{array}{c}\text { Jumlah } \\
\text { citra } \\
\text { tidak } \\
\text { berhasil } \\
\text { dikenali }\end{array}$ & $\begin{array}{c}\text { Jumlah } \\
\text { Citra } \\
\text { berhasil } \\
\text { dikenali }\end{array}$ & $\begin{array}{c}\text { Jumlah } \\
\text { citra } \\
\text { tidak } \\
\text { berhasil } \\
\text { dikenali }\end{array}$ \\
\hline 10 & 27 & 3 & 25 & 5 & 21 & 9 \\
\hline 30 & 26 & 4 & 27 & 3 & 21 & 9 \\
\hline 50 & 27 & 3 & 27 & 3 & 22 & 8 \\
\hline 100 & 25 & 5 & 25 & 5 & 24 & 6 \\
\hline
\end{tabular}

Pengujian dilakukan sebanyak 360 kali pengujian dengan jumlah citra sebanyak 30 citra. Masing-masing citra diuji dengan jumlah neuron $\mathrm{n}=10, \mathrm{n}=30, \mathrm{n}=50$, dan $\mathrm{n}=100$ dan dengan tiga fungsi aktivasi yaitu sigmoid, sein dan radial basis.

Setelah hasil pengujian diketahui, maka kita dapat mengetahui persentase keberhasilan program yang telah dibuat. Persentase keberhasilan program dapat dilihat pada tabel 2 berikut :

Tabel 2. Persentase keberhasilan program

\begin{tabular}{|c|c|c|c|c|}
\hline Nama & \multicolumn{4}{|c|}{ Hidden Neuron } \\
\cline { 2 - 5 } Fungsi & Neuron & Neuron & Neuron & Neuron \\
Aktivasi & 10 & 30 & 50 & 100 \\
\hline
\end{tabular}

\begin{tabular}{|l|c|c|c|c|}
\hline Sigmoid & $90 \%$ & $86,6 \%$ & $90 \%$ & $83,3 \%$ \\
\hline Sine & $83,3 \%$ & $90 \%$ & $90 \%$ & $83,3 \%$ \\
\hline $\begin{array}{l}\text { Radial } \\
\text { Basis }\end{array}$ & $70 \%$ & $70 \%$ & $73,3 \%$ & $83,3 \%$ \\
\hline
\end{tabular}

Berdasarkan hasil dari masing-masing proses pengujian, diperoleh bahwa pengujian dengan fungsi aktivasi sigmoid memiliki persentase akurasi yang lebih baik dari yang lainnya dengan nilai persentase keberhasilan program mencapai $90 \%$.

Penambahan jumlah hidden neuron dapat meningkatkan akurasi namun hanya sampai batas tertentu. Hal ini dapat dilihat pada hidden neuron 30 dan hidden 50 ada kenaikan persentase keberhasilan program, tetapi pada hidden neuron 100 persentase keberhasilan program menurun kembali.

\section{KESIMPULAN DAN SARAN}

Dari hasil penelitian, dapat disimpulkan bahwa:

1. Perbedaan mineral kalsit dan dolomit pada citra hasil thin slice batuan karbonat dapat dikenali melalui perbedaan warna dan pola pada citra. Mineral kalsit memiliki warna dominan hitam dan pola berbentuk dua belahan, sedangkan dolomit memiliki warna dominan merah dan pola berbentuk satu belahan.

2. Algoritma Extreme Learning Machine efektif digunakan untuk mengidentifikasi citra hasil thin slice batuan karbonat dengan ekstraksi ciri menggunakan metode Gray Level Co-occurrence Matrix, fungsi aktivasi sigmoid dan hidden neuron $=50$ sehingga menghasilkan persentase akurasi sebesar $90 \%$.

\section{DAFTAR PUSTAKA}

Badan Penelitian dan Pengembangan Provinsi Sumatera Utara, (2011), Studi Pemanfaatan Batugamping di Kabupaten Tapanuli Selatan, Pemerintah Provinsi Sumatera Utara, Medan. 
Adler, J., (2013), Pengenalan Pola Warna Image dengan Jaringan Syaraf Tiruan pada MATLAB, Seminar Nasional Teknologi Informasi dan Komunikasi, 45-50.

Arifin, dan Tumanan, O., (2011), Pengenalan Pola Sidik Jari Menggunakan Jaringan Saraf Tiruan dengan Metode Pembelajaran Backpropagation, Jurnal Aplikasi Fisika, 7(1) : 1-11

Nugroho, F., Cholissodin, I., dan Suprapto., (2018), Implementasi Extreme Learning Machine Untuk Deteksi Dini Infeksi Menular Seks (IMS) Pada Puskesmas Dinoyo Kota Malang, Jurnal Pengembang Teknologo Informasi dan Komputer, 2(11) : 44004406.

Geost, F., (2016), Dolomit adalah Mineral Bukan Batuan,https://www.geologinesia.com/ 2016/02/dolomit-adalah-mineralbukan-batuan.html

Smith, (2017), Smith College-Geology 222b Petroghraphic Data File Calcite, http://www.science.smith.edu/geoscie nces/petrology/Petrography/calcite/cal cite.html

Nelson, A., (2014), Tectosilicates, Carbonates, Oxides, \& Accessory Minerals, https://www.tulane.edu/ $\sim$ sanelson/een s211/tectosilictes\&others.htm

Kumaseh, M., R., Latumakulita, dan L., Nainggolan, N., (2013), Segmentasi Citra Digital Ikan Menggunakan Metode Thresholding, Jurnal Ilmiah Sains, 13(1) : 75-79.

Firman, A., (2007), Dasar - dasar Pemprograman Matlab, http://ilmukomputer.com

Arifin, dan Tumanan, O., (2011), Pengenalan Pola Sidik Jari Menggunakan Jaringan Saraf Tiruan dengan Metode Pembelajaran Backpropagation, Jurnal Aplikasi Fisika, 7(1) : 1-11

Pandiangan, T., D., (2017), Identifikasi Kelainan Pada Jantung Menggunakan Extreme Learning Machine (ELM), Fakultas Ilmu Komunikasi dan Teknologi Informasi, Universitas Sumatera Utara, Medan
Sirait, T. R., (2017), Identifikasi Penyakit Kulit Menggunakan Extreme Learning Machine, Fakultas Ilmu Komputer dan Teknologi Informasi, Universitas Sumatera Utara, Medan. 